\title{
Geothermal energy for desalination to secure food security: case study in Djibouti
}

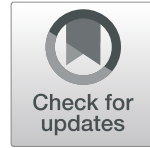

D. Chandrasekharam ${ }^{1,2^{*}}$ (D) A. Lashin ${ }^{3}$, Nassir Al Arifi ${ }^{4}$, Abdulaziz M. Al-Bassam ${ }^{5}$ and C. Varun ${ }^{6}$

\begin{abstract}
Background: By the year 2025, nearly 3.5 billion people in the world will have no water, including 900,000 from Djibouti. The economic losses caused by the 2000-2012 drought pushed the country to a state of disaster. This has devastated Djibouti's economy and left millions hungry. This is due to the country's inability to grow food and dependence on the food imports. The 5 US\$ million granted by the WB was not able to reduce the hunger and prevent further increase in poverty and social unrest due to want of food and water. This paper provides a solution to create a self-sustainable society that can live above the current poverty line.

Methods: The study was carried out based on field investigation and published literature. Desalination cost comparison between fossil fuel-based technology and renewable energy-based technology was carried out based on data from working plants. These data were used to analyse the cost-benefit ratio of fresh water generated from seawater and its use in securing food to the population.

Results: By developing the geothermal resources, the country can be lifted above the poverty line. What the country needs, to come out of this crisis, is fresh water supply. The country's geothermal energy resource can generate $900 \times 10^{6} \mathrm{kWh}$ of electricity. The electricity required to generate $1000 \mathrm{~m}^{3} /$ day $\left(10 \times 10^{6} \mathrm{~kg} /\right.$ year $)$ of fresh water from the sea is about $11 \times 10^{6} \mathrm{MWh}$. The cost of desalinated water through geothermal energy sources is $1.6 \mathrm{US} \$ / \mathrm{m}^{3}$ which is far less than the desalinated water generated through any other energy source. Billions of dollars given as aid for poverty alleviation can be utilized to develop geothermal power plants to provide permanent food security to the country.

Conclusions: The rural population of Djibouti can improve their socio-economic status and secure food security and eradicate hunger through geothermal energy source. Local governments also should play an important role in advising the funding institutions to develop geothermal power projects to support agricultural activity and create employment to the rural population and support a sustainable society.
\end{abstract}

Keywords: Geothermal energy, Desalination, Food security, Djibouti, Sustainable society

\section{Introduction}

In the future, countries will be stressed due to nonavailability of fresh water to meet agricultural demand and human consumption. With the ever-growing population, fresh water availability is becoming an issue, especially in countries that depend completely on virtual water trade (VWT). According to the World Resources Institute [1], by 2025 , nearly 3.5 billion people in the world will have no water. This is especially true with countries like Djibouti that has no defined drainage

\footnotetext{
* Correspondence: dchandra50@gmail.com

${ }^{1}$ India Institute of Technology Hyderabad, Hyderabad 502285, India

${ }^{2}$ King Saud University, Riyadh, Saudi Arabia

Full list of author information is available at the end of the article
}

system, surface water ponds, lakes or rivers. Day to day existence is becoming difficult for the rural people in these countries, and people are driven to poverty due to lack of fresh water for food production (http://www.wri. org/our-work/topics/water accessed on 08/16/2015). Countries have explored options to obtain fresh water from seawater. Desalination technology to obtain fresh water from sea has matured now. With geothermalsourced desalination method becoming a viable costeffective option to get fresh water from the sea, countries that have unlimited geothermal source soon will be food and water secured [2]. The Republic of Djibouti, with a population of 963,585 , extends over an area of about

(c) The Author(s). 2019 Open Access This article is distributed under the terms of the Creative Commons Attribution 4.0 International License (http://creativecommons.org/licenses/by/4.0/), which permits unrestricted use, distribution, and reproduction in any medium, provided you give appropriate credit to the original author(s) and the source, provide a link to the Creative Commons license, and indicate if changes were made. 
$23,200 \mathrm{~km}^{2}$. The country is strategically located for sea route and is a centre of economic activities. These activities are service oriented, supporting the civilian and military infrastructure facilities that includes transportation, communication, construction, banking and other such facilities. These transit trade economic activities contribute nearly $80 \%$ to the country's gross domestic product (GDP). The rural population depends on agricultural and pastoral activities that contribute $4 \%$ to the country's GDP (Japan International Cooperation Agency; [3]). Factors such as low rainfall and non-availability of water for irrigation have kept the population below the poverty line. The drought the country experienced during 2011-2012 has further lowered its economic status. The economic losses caused by this drought pushed the country to disaster, and the country is unable to recover from this crisis. The population of the country has plunged into economic crisis, and its food and water security is drastically affected (United Nations Educational, Scientific and Cultural Organization; [4]). What the country needs, to come out of this crisis, is fresh water supply. The financial institutions giving aids to uplift the socio-economic status of the rural population should realise this (Asian Development Bank: [5]). These aid institutes' goals and focus are misplaced. For example, when the rainfall is scanty and groundwater resources are poor, projects cannot aim at repairing pumps, deepening the wells, drilling additional wells, training well-digging techniques, constructing dams etc. This only implies casual attitude of the funding agencies (United Nations International Children's Emergency Fund: [6]). The country has excellent geothermal energy resources that are lying untapped for centuries. This paper discusses the solution to uplift the poverty condition of Djibouti permanently by providing fresh water through geothermal energy-based desalination. This method is the most cost-effective process that can provide, besides fresh water, employment to the rural population and enhances the agricultural GDP of the country substantially.

\section{Methodology}

Geological description of the study area has been discussed based on published geological maps. Water resource status of Djibouti is documented based on various reports presented both by national and international agencies. The geothermal resource analyses have been carried out based on field data collected during the field work by the authors and from the published literature cited in the paper. Capital cost of desalination technology, levelized cost of fresh water generated through desalination technology using fossil fuels and geothermal energy resources have been documented based on published date cited in the text.

\section{Results of the study}

The present study analyses the current and future water resources status of Djibouti based on the geological formations hosting the aquifers, the estimated water that is available in these volcanic aquifers, hydrogeological characteristics of these aquifers in terms of transmissivity and the amount of irrigated land available for raising food crops. Since there are no active drainage systems in Djibouti, information related to the above aspect is meager. All the information available from the water resources department of the Government of Djibouti and the reports published by the funding agencies like the World Bank and International Monitory Fund are utilized [7]. Based on the water availability, the country's food status is analysed in terms of available land for irrigation, fresh water needed to raise crops, current mitigation strategies adopted by the country to meet fresh water demand and the future water needed to reduce food imports. A detailed account on the available geothermal resources have been discussed in terms of location of the geothermal sites, number of surface manifestations, surface temperatures of the thermal springs, geothermal bore well logs and measured bottom hole temperatures from the geothermal wells. Cation geothermometry and oxygen and hydrogen isotopic signature of the thermal fluids have been used to estimate the reservoir temperatures of $\mathrm{L}$. Asal (Lake Asal), Hanle and L. Abhe (Lake Abhe) geothermal sites. The amount of electricity that can be generated using the geothermal resources from $\mathrm{L}$. Asal, Hanle and L. Abhe geothermal sites have been highlighted. Since the country is devoid of natural surface water drainage systems and the groundwater resources are scanty, future food and water security of the country has been discussed in terms of virtual water trade and strategies to reduce dependency on food imports by generating fresh water adopting desalination technology. Current desalination technologies have been described, and the $\mathrm{CO}_{2}$ (carbon dioxide) emissions associated with such technologies using fossil fuels have been elaborated. The advantages of generating fresh water through desalination technology using geothermal resources have been discussed including the reduction in $\mathrm{CO}_{2}$ emissions that can be achieved, and the capital cost of implementing such technologies and the cost of the final product (fresh water) has been calculated. The cost estimations are made based on actual data on fresh water generated from desalination plants being operated using geothermal energy. The above results are discussed in detail in the following sections.

\section{Water resource status}

The average annual rainfall of Djibouti is less than $200 \mathrm{~mm}$, and a large part of it ( 83\%) evaporates. Surface runoff and baseflow constitute about $12 \%$, and only $5 \%$ infiltrates into 
the ground, recharging the aquifers [3]. There is no defined natural drainage network in Djibouti.

Djibouti has two main aquifers: (i) top unconfined alluvial aquifers and (ii) deeper hard rock aquifers hosted by the volcanic flows (The Stratoid Series, Fig. 1). The alluvial aquifers (transmissivity 0.4 to $163 \mathrm{~m}^{2} / \mathrm{h}, 4.5 \times 10^{-2} \mathrm{~m}^{2} / \mathrm{s}$ ) are located along the wadis and are the main source of water to the rural population, supporting agricultural and livestock's need. The water is extracted through shallow open wells or tube wells. Annually, over 4 million $\mathrm{m}^{3}$ of water/year is withdrawn from these aquifers for agricultural purpose [8]. The volcanic aquifers (Stratoid and
Dalha basalt aquifers) are transboundary aquifers shared by Djibouti and Ethiopia. The transmissivity of the basalt aquifers varies from $1.5 \times 10^{-4}$ to $5.7 \times 10^{-1} \mathrm{~m}^{2} \mathrm{~s}^{-1}$ for Stratoid series and $2.9 \times 10^{-6}$ to $1.6 \times 10^{-2} \mathrm{~m}^{2} \mathrm{~s}^{-1}$ for Dalha basalts [8]. The Stratoid series occupies an area of $9000 \mathrm{~km}^{2}$ with a thickness of $1300 \mathrm{~m}$, and in Ethiopia, these basalts are drained by Awash River [8]. Nearly 12 million $\mathrm{m}^{3}$ of water per year is being supplied by the basalt aquifers to the Djibouti town. Agriculture activity in Djibouti is very low due to lack of sufficient surface and groundwater sources. Sometimes, the intensity of rain is so severe that the region gets flooded with

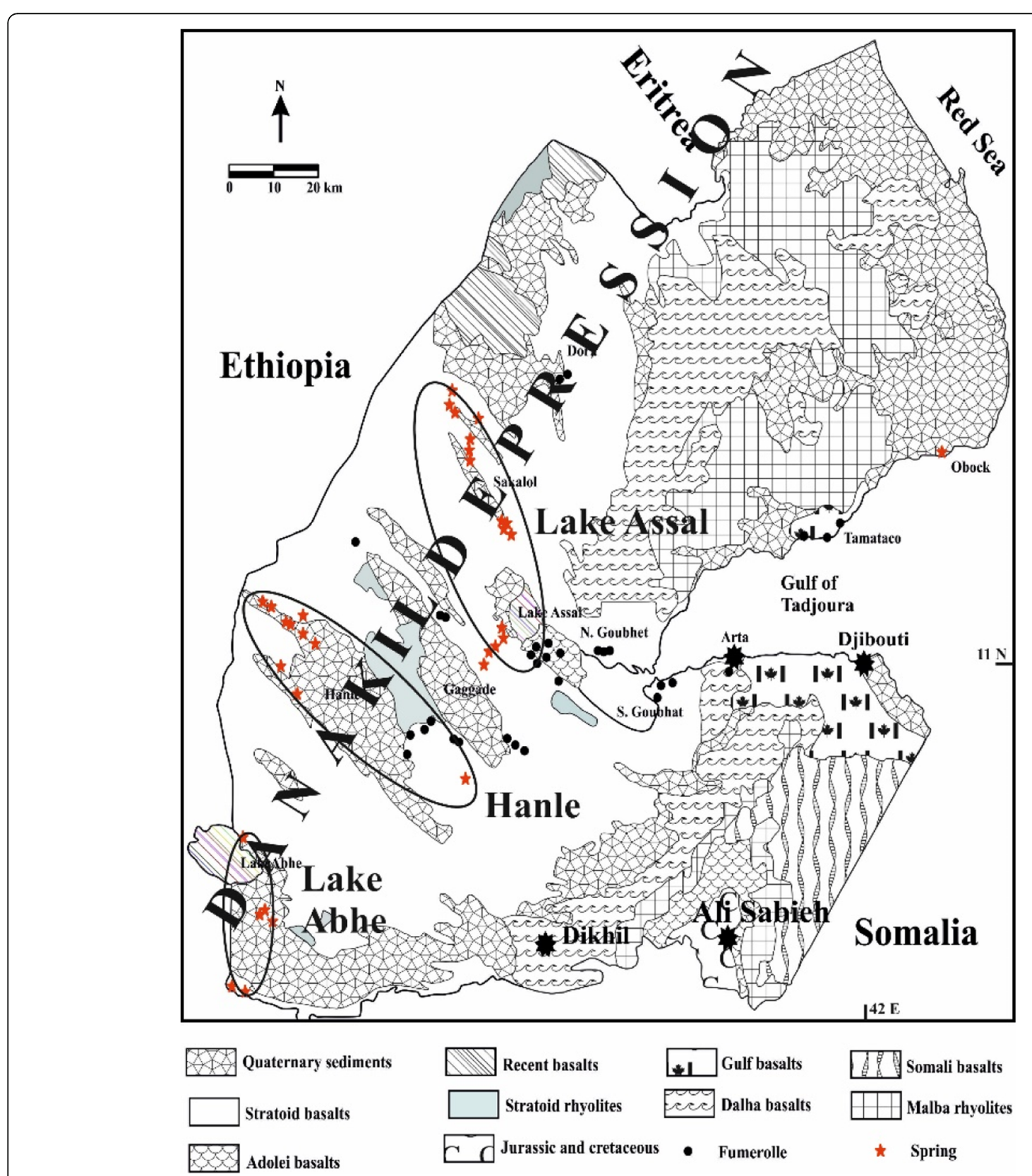

Fig. 1 Simplified geological map of Djibouti (adapted from [8]) 
surface runoff exceeding the infiltration. The irrigated land is about 1250 ha, and the crops grown include tomatoes, melon, onions and pepper. No major food crops (i.e. cereals, pulses, rice, wheat, barley) are grown, and the country depends heavily on virtual water trade (VWT) and imports all these essential food items and fossil fuels as well. Nearly $80 \%$ of food products are imported from Ethiopia. In addition, Djibouti is growing wheat in Ethiopia over a land of 5000 ha to eliminate poverty in rural regions. But due to the involvement of large intermediate supply chain engaged in the production of wheat in Ethiopia, the unit cost of wheat grown in Ethiopia is much higher than that of imported wheat. Thus, VWT is not of great value to the economy of the country. In addition, the country does not have adequate mechanism to preserve the food products thus adding to additional loss to the economy (African Union Semi-Arid Food Grain Research and Development: [9]). The self-sufficiency status for food products is very low and is about $<6 \%$ $[3,10]$. Agricultural activity is concentrated in Dikhil, Djibouti and Arta (Fig. 1). Besides agriculture, animal husbandry is a livelihood for many people living in the rural areas. Meat export is a major income for the rural population. The livestock are left to graze in the neighbouring countries (Somalia and Ethiopia) due to dearth of grazing land, and this is a major source of income for the rural population (zero investment on fodder). Due to consecutive droughts, the country is always under intense poverty. In 2014, the Japanese International Cooperation Agency [3] drafted a detailed plan in 2014 to augment the water supply to three localities in the southern Djibouti to help the nomads to grow food. It is not known whether this project was implemented if so the outcome of the project.

\section{Geothermal resource status}

Djibouti is located within the Danakil depression that was formed due to the extension regime tectonics of the Red Sea and the Gulf of Aden. Djibouti physiographically is a part of the East African Rift, floored by stretched oceanic/ continental basic crust and flanked on the east and west side by the Jurassic and Mesozoic formations (Fig. 1). The upper mantle is located at a depth of $6 \mathrm{~km}$ in this region, and hence, this region experiences high heat flow values [11]. Djibouti experienced two major episodes of volcanism, one between 22 and $14 \mathrm{Ma}$ (Miocene) and the second one between 4 and $7 \mathrm{Ma}$ (mega-annum) (Pliocene-Pleistocene). The Miocene volcanic rocks are grouped under Adelei, Mabla and Dalha series while the younger rocks are named as Stratoid Series. The Afar floor is represented by the Stratoid Series (basalts) that presumably underlain by basic crust of oceanic and/or continental material (Fig. 1) while landmasses on either side of the Afar are represented by Nubian-Arabian shield and post-Nubian-Arabian shield members [12-15]. The Stratoid Series basalts, covering an area of about 55, $000 \mathrm{~km}^{2}$, with an average thickness of $1.5 \mathrm{~km}$, extend beyond Ethiopian rift and host major geothermal reservoirs in Djibouti and in Ethiopia (Fig. 2) [17-19]. The Stratoid Series basalts in Ethiopia are termed as Adolei basalts [20-22]. Major volcanic activity that occurred

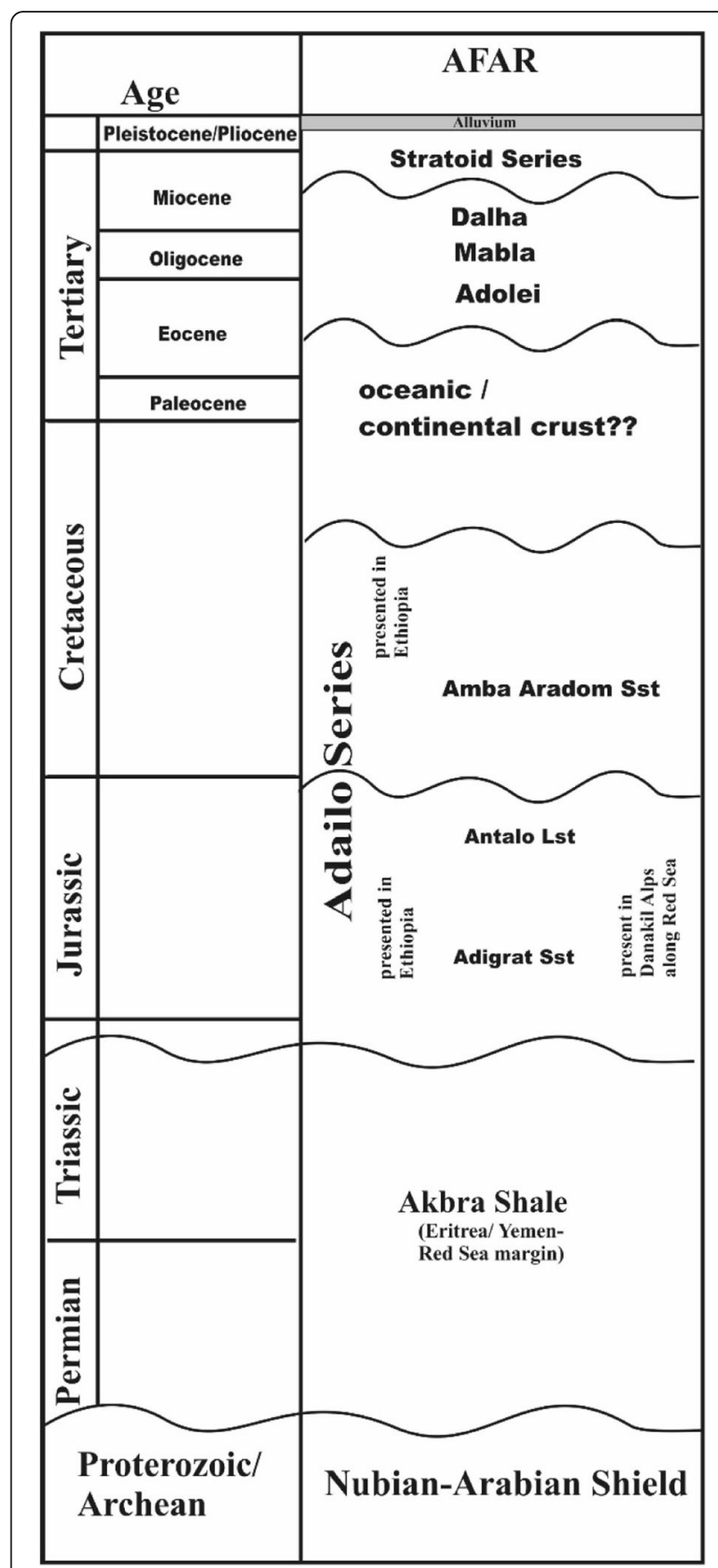

Fig. 2 Simplified stratigraphy of Afar. In Djibouti, the Eocene and post-Eocene members directly lie over the Oceanic/Continental basic crust (adapted after [16]) 
between 4 and $0.4 \mathrm{Ma}$ was responsible for the opening of the Tadjourah Gulf [20], east of Djibouti (Fig. 1).

\section{Resource characterisation}

The geothermal systems in Djibouti comprises of boiling springs, thermal pools, fumaroles and travertine deposits. The surface temperature of the thermal waters is around $99^{\circ} \mathrm{C}$. The geothermal manifestations are spread around Lake Asal (L. Asal), Hanel in central Djibouti and Lake Abhe (L. Abhe) in the west (Fig. 1). The thermal waters are channelled through series of NW-SE (Northwest-Southeast) trending parallel extensional faults that were developed during the rifting regime. Due to the vertical movements along the faults, graben and horst structures were developed. L. Asal thus lies $150 \mathrm{~m}$ below the sea level (below Tadjourah Gulf, Fig. 1). Magneto-Telluric geophysical survey around L. Asal indicates high-temperature zones at about $6 \mathrm{~km}$ depth indicating the presence of $1200{ }^{\circ} \mathrm{C}$ geotherm at this depth $[11,23]$. This is confirmed from the geothermal gradient recorded from exploratory drill-holes which gave values around $250{ }^{\circ} \mathrm{C} / \mathrm{km}$ $[11,24,25]$. In addition to MT survey, self-potential survey was carried out around L. Asal that indicated that the seawater is the main feeder to the geothermal system at this site. The geothermal gradient decreases to $80^{\circ} \mathrm{C} / \mathrm{km}$ towards Hanle $\left(\sim 80^{\circ} \mathrm{C} / \mathrm{km},[19,25]\right)$ (Fig. 1) giving rise to low enthalpy geothermal systems in this area. The L. Abhe geothermal system is associated with active volcanoes in the Danakil Depression located in Ethiopia (Erta Ale and Damah Ale), with Awash River as the main source recharging the geothermal reservoirs. The Awash River, that originates in the southern part of the East African Rift
(EAR) valley, discharges into the $\mathrm{L}$. Abhe. This is a landlocked lake which experiences heavy evaporation, resulting in a high concentration of salts in the lake water [18]. The temperatures of thermal waters here vary from 84 to $98^{\circ} \mathrm{C}$ [18]. In addition to thermal springs, this area hosts several linear mounds of travertine indicating large presence of $\mathrm{CO}_{2}$ in the geothermal system. The Stratoid Series and the Adigrat sandstone host the geothermal systems in Djibouti (Fig. 2). The characteristics of the three geothermal sites (L. Asal, Hanel and L. Abhe) are described below.

The geothermal provinces of Djibouti can be divided into (i) high-temperature provinces represented by L. Asal on the east and L. Abhe on the west and (ii) low- to mediumtemperature province represented by Hanle at the centre of the country (Fig. 1). The surface temperatures of the thermal springs along with the reservoir temperatures are given in Table 1.

The geothermal province around L. Asal being hightemperature system, it is proposed to install $112 \mathrm{MWe}$ (megawatt electricity; $932 \times 10^{6} \mathrm{kWh}$ : kilowatt-hour) power plant (steam and binary plants, [29]). The Hanel and L. Abhe geothermal systems are low and medium enthalpy systems respectively. All the bore wells drilled around Hanle and L. Abhe are proposed to be developed into stand-alone electricity generation centres and connected by micro-grids to meet the local rural population demand. Based on extensive worldwide investigation on the performance of such wells, it is demonstrated that each such well (medium and low enthalpy systems) can generate $4 \mathrm{MWe}$ at the well head itself (binary power plants) $[10,18,30]$. Although the

Table 1 Surface temperatures of selected thermal springs from the three provinces and the reservoir temperatures

\begin{tabular}{|c|c|c|c|}
\hline Area & Surface T ${ }^{\circ} \mathrm{C}$ & $\mathrm{Na} / \mathrm{K}^{*}$ & Ref \\
\hline L Abhe 1 & 95 & 152 & 1 \\
\hline L Abhe 2 & 98 & 152 & 1 \\
\hline L Abhe 3 & 96 & 123 & 1 \\
\hline L Abhe 4 & 99 & 144 & 1 \\
\hline LAsal 1 & 71 & 175 & 2 \\
\hline LAsal 2 & 69 & 170 & 2 \\
\hline L Asal 3 & 83 & 170 & 2 \\
\hline Hanle & 60 & 124 & 3 \\
\hline
\end{tabular}

Source: 1 [18], 2 [26], 3 [27]; * geothermometry: [28] 
cation geoindicators $[28,31]$ indicate the geothermal reservoir temperatures to be between 150 and $170{ }^{\circ} \mathrm{C}$ for L. Asal and L. Abhe geothermal sites respectively (Table 1), the oxygen and hydrogen isotope signatures (Fig. 3) in the thermal waters indicate temperatures > $200{ }^{\circ} \mathrm{C}$, at depth of $1500 \mathrm{~m}$ [32].

Based on exploratory bore well data, it is proposed to build 112 MWe $\left(932 \times 10^{6} \mathrm{kWh}\right)$ power plant at L. Asal geothermal site by 2020 and several 1 MWe $(9 \times$ $10^{6} \mathrm{kWh}$ ) power plants around L. Abhe and Hanle geothermal sites. This quantity of electricity is surplus to Djibouti, considering its population $(\sim 900,000,[19,29$, 32]). This energy can be utilized for desalination of seawater, and fresh water thus generated can be provided to the population to support their agricultural and domestic needs and make the country food secured and free the country from VWT.

\section{Project cost to develop geothermal power plants}

The project cost for developing geothermal power plant from different reservoir temperatures is given in Table 2.

These costs are similar to that estimated by Stefánsson [35] based on actual costs incurred for the Iceland geothermal systems and are similar to that modelled by Nusiaputra et al. [34] and Assad et al. [30]. The installation costs, for resource temperatures beyond $140{ }^{\circ} \mathrm{C}$, varies between 2.5 and 6.5 million US\$ per megawatt electricity [35, 36]. However, for EGS (Enhanced Geothermal Systems), the investment costs will be higher at present [37].

\section{Cost of electricity}

The levelized cost of electricity generated from various renewable and fossil fuel-based power plants are shown in Fig. 4. These are based on actual field-based data [38]. Unlike in the past, currently, $\mathrm{CO}_{2}$ emissions from power plants dictate the cost of power as carbon emissions are becoming part of economic equations. Thus, clean coal power plants have higher unit cost due to imbedded cost incurred for cleaning the coal compared to plants operated by low $\mathrm{CO}_{2}$-emitting energy source like geothermal. The $\mathrm{CO}_{2}$ emissions by geothermal power plants are far less compared to power plants operated by fossil fuels (Fig. 5).

The levelized cost of geothermal power shown in Fig. 4 is without subsidy unlike solar pv (photovoltaic) where the present cost is lower than that shown in Fig. 4. Even though the levelized unit cost of electricity generated by conventional energy sources is lower compared to geothermal energy and clean coal, the environmental cost to stabilize global climate is not embedded in the levelized cost. Similarly, in the case of solar pv-supported power plants, the solar panels while generating electricity do not emit $\mathrm{CO}_{2}$, but the amount of $\mathrm{CO}_{2}$ emissions during the manufacturing of silicon solar cells is considerable and is higher than that emitted by geothermalsourced power plants. The $\mathrm{CO}_{2}$ emissions during the life cycle of solar sc-Si (single-cell silicon) are considerable [40], and this component is not taken into account in the cost factor of electricity generated by solar pv power plants. Thus, to manufacture single-cell module (sc-Si), $4620 \mathrm{kWh} / \mathrm{m}^{2}$ of energy is required, and for multi-cell

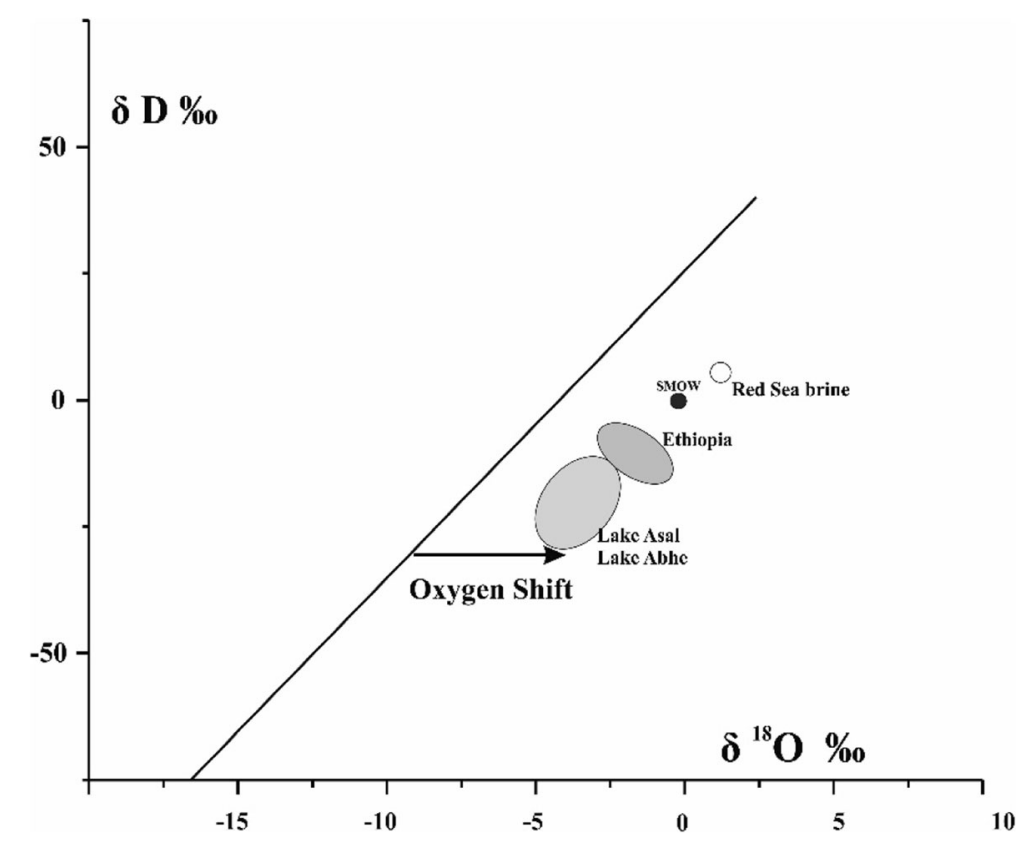

Fig. 3 Oxygen-hydrogen isotope diagram showing high-temperature exchange between thermal and host rocks 
Table 2 Project cost of geothermal binary power plants

\begin{tabular}{|c|c|c|c|}
\hline \multirow[t]{2}{*}{ Power generated KWe } & \multicolumn{2}{|c|}{ Resource Temperature ${ }^{\circ} \mathrm{C}$} & \multirow[t]{2}{*}{ O \& M cost US\$/year } \\
\hline & 120 & 140 & \\
\hline & \multicolumn{2}{|c|}{ Capital cost Us\$/Mwe $10^{6}$} & \\
\hline 500 & 1.8 & 1.7 & 30000 \\
\hline 1000 & 1.7 & 1.5 & 44000 \\
\hline
\end{tabular}

Adapted from $[33,34]$

modules (mc-Si), $2128 \mathrm{kWh} / \mathrm{m}^{2}$ of energy is required [41-45]. Currently, the solar cell industry is supported by fossil fuel-based power plants. The $\mathrm{CO}_{2}$ emission from the manufacture of single-cell sc-Si module is $5810 \mathrm{~kg}$ of $\mathrm{CO}_{2}$ and for the manufacture of multi-cell mc-Si module is $2300 \mathrm{~kg}$ of $\mathrm{CO}_{2}$ [41-45].

Thus, the unit cost of electricity generated by geothermal power plants (without subsidy) is very low (Fig. 4). This cost has not increased since 2001. In 2001, the cost of electricity generated from geothermal plants was 10 US\$ cents/kWh and the electricity generated from hydro was around 12 US\$ cents/kWh [46]. However, the cost of electricity generated by solar pv was much higher compared to the above renewable energy sources, and it was 125 US\$ cents/KWh [46] and has increased substantially in the current period (Fig. 4). The low unit cost of electricity from geothermal power plants is due to improved drilling and heat exchanger (increase in heat exchange efficiency) technology. In the case of solar pv, the increase is related to the cost of raw material (pure quartz), extraction of metallurgical and electronic grade silicon and associated components for the assembly and deployment of the panels. Besides this, the cost will also include expenses incurred for the storage batteries and carbon emission-related costs by the solar cell manufacturing industries [41-45]. In the case of geothermal power plants, the heat source is free but greater than $45 \%$ of the investment cost is spent in drilling wells.

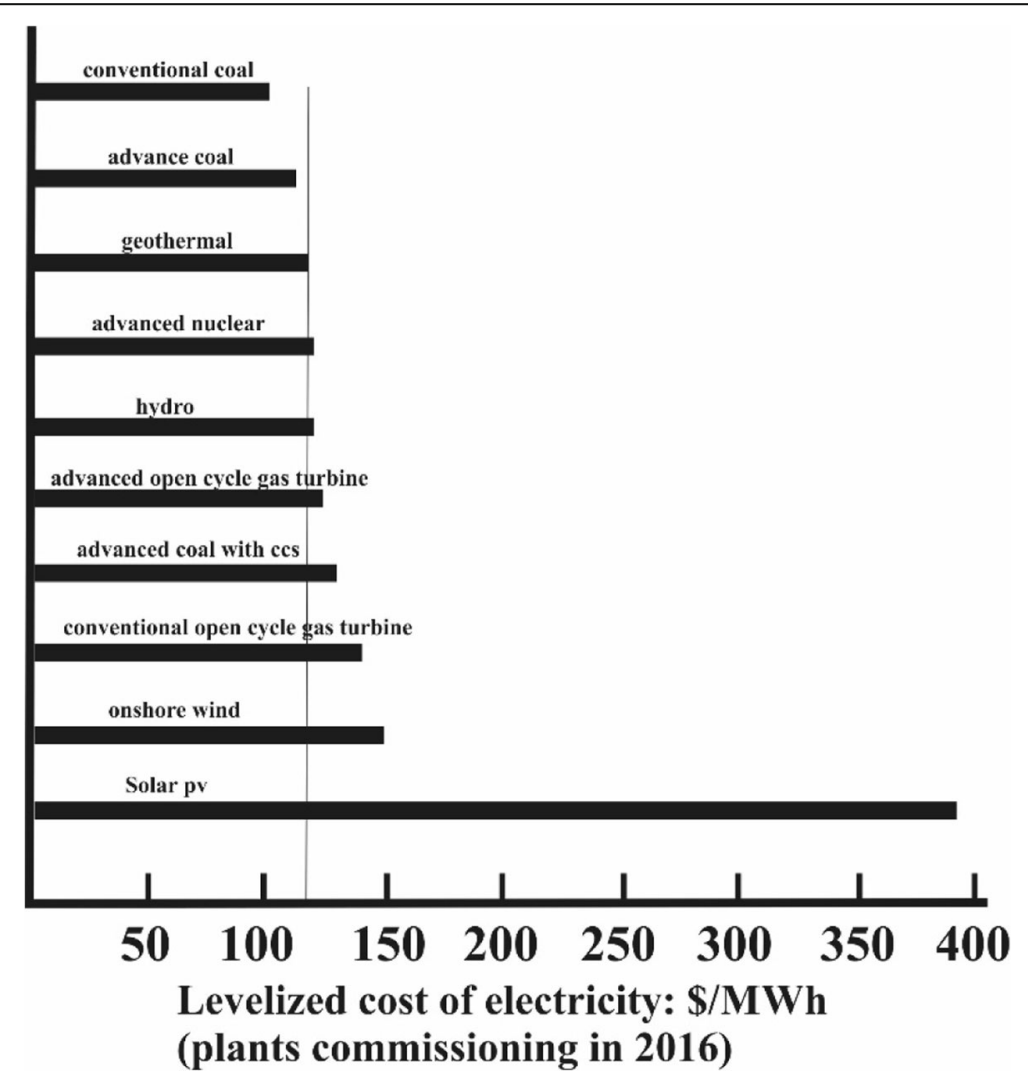

Fig. 4 Levelized cost of electricity generated by conventional and non-conventional energy sources (adapted from [38]) 


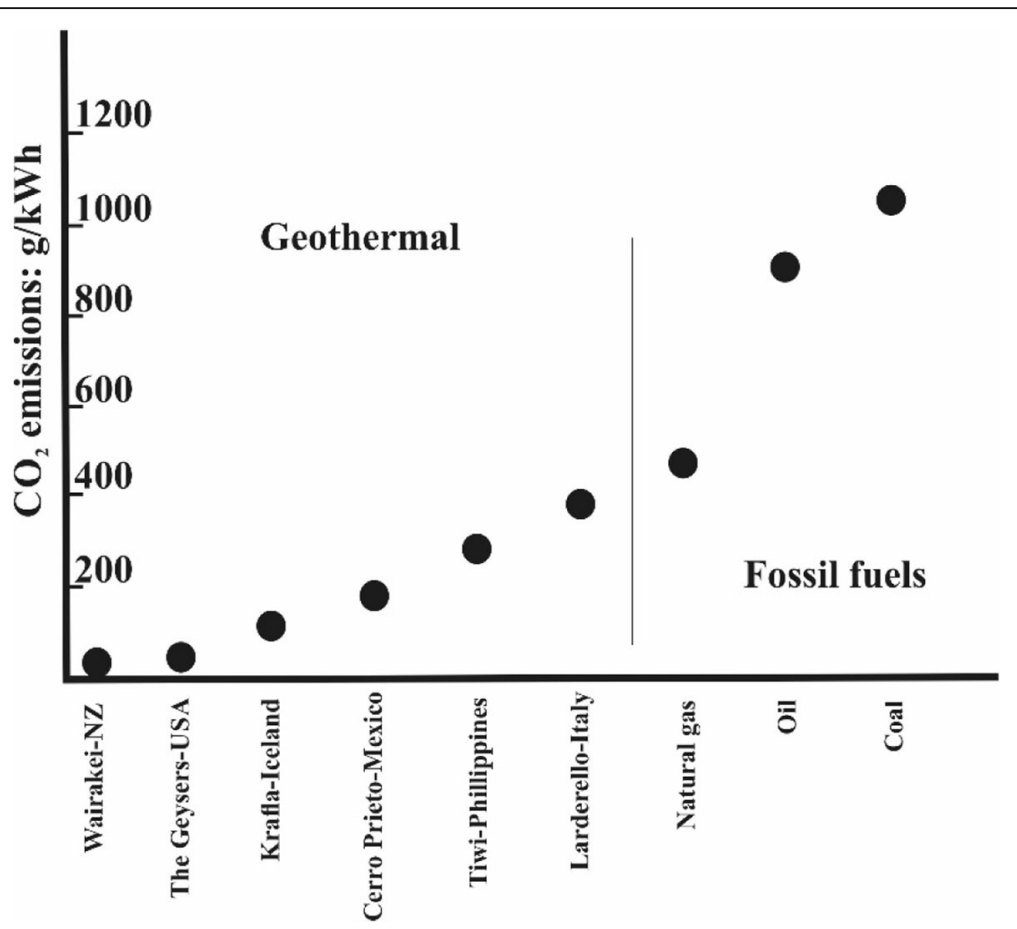

Fig. $5 \mathrm{CO}_{2}$ emissions from geothermal and fossil fuels power plants (adapted from [39]). Limestone is the geothermal reservoir in Larderello

\section{Desalination}

Water and food security are the largest issues to all the sub-Saharan countries. These countries are into VWT and depend heavily on food imports, and thus, their food security is at risk. Djibouti falls into this category. With exponential population growth, it is becoming extremely difficult for these countries to manage water resources, especially for agricultural purpose. These countries have to turn to the sea to get fresh water and solve the future food problem. Egypt has realised this issue, even though the country has perennial supply of fresh water from the Nile to support agriculture. Egypt has established a desalination plant in 1912, generating $75 \mathrm{~m}^{3}$ /day of fresh water from the Mediterranean Sea. Commercial scale desalination plant was commissioned by Kuwait in 1957 at Shuwaikh, generating $4600 \mathrm{~m}^{3} /$ day of fresh water from the Persian Gulf. Currently, desalination plants are able to generate greater than 100, $000 \mathrm{~m}^{3} /$ day of fresh water from the seawater through reverse osmosis $(\mathrm{RO},[2,47]$. The most important and commonly followed desalination methods include multieffect evaporation/distillation (MED), multistage flash distillation (MSF), mechanical vapour compression (MVC), electro dialysis (ED) and reverse osmosis (RO). These technologies consume large amount of energy (electricity) and emit substantial volume of $\mathrm{CO}_{2}$. Even the $\mathrm{RO}$ technology, that is low intensive energy technology, also consumes about $4 \mathrm{kWh} / \mathrm{m}^{3}$ and emits large amount of $\mathrm{CO}_{2}$ [48]. For example, the seawater $\mathrm{RO}$ plant in Sydney generates $25,000 \mathrm{~m}^{3} /$ day of fresh water ejecting $954 \mathrm{t}$ of $\mathrm{CO}_{2}$ /day [48]. Because these are energy-intense desalination technologies using fossil fuels, the fresh water thus obtained is also expensive.

The unit cost of desalinated water was around 0.5 US $\$ \mathrm{~m}^{3}$ (when the cost of fossil fuels was $\sim 10 \mathrm{US} \$ /$ ton [49]. The energy required for generating $1000 \mathrm{~m}^{3} /$ day of $\left(10 \times 10^{6} \mathrm{~kg} /\right.$ year $)$ fresh water from the sea is about $11 \times$ $10^{6} \mathrm{MWh}$. The $\mathrm{CO}_{2}$ emitted by 1 MWe $(\sim 613 \times$ $10^{6} \mathrm{MWh}$ ) of fossil fuel-supported power plant is about $817 \mathrm{~kg}[10,50,51]$. Amongst the desalination technologies commonly adopted currently, MED gives most optimum results in terms of cost, energy consumption and $\mathrm{CO}_{2}$ emissions and salinity concentration of the feed water (Table 3).

Generation of large quantities of fresh water required for agricultural (including livestock) purpose is constrained by high cost involved and the $\mathrm{CO}_{2}$ emissions associated with these fossil fuel-sourced desalination plants. These issues can be mitigated by using renewable energy as the source. The renewable energy sources that are adopted in the generation of fresh water through desalination technology include solar pv, solar thermal, wind and geothermal. In terms of energy input and $\mathrm{CO}_{2}$ emissions, solar, wind and geothermal sources play equal role but geothermal scores in terms of unit cost of fresh water generated (Table 4). It is apparent that the geothermal-sourced desalination plants can generate fresh water at low cost and is the most viable method 
Table 3 Energy requirement, capital and generation cost and $\mathrm{CO}_{2}$ emissions for different desalination technologies

\begin{tabular}{|l|c|c|c|c|}
\hline & MVC & MSF & MED & RO \\
\hline Production Capacity & $3 *$ & $25^{*}$ & $10^{*}$ & $6^{*}$ \\
\hline Generation Cost USS/1000 L & 0.7 & 1.1 & 0.8 & 0.7 \\
\hline Energy $(\mathrm{kWh} / 1000 \mathrm{~L})$ & 7 & 4 & 2 & 5 \\
\hline $\mathrm{CO}_{2}$ emissions $(\mathrm{kg} / 1000 \mathrm{~L}) * *$ & 9 & 4 & 2 & 7 \\
\hline
\end{tabular}

Adapted from $[2,47,48,52]$; million litres; ${ }^{* *} \mathrm{kgCO}_{2} / \mathrm{MWh}=817,[10]$

for countries like Djibouti that has abundant geothermal energy resources. The advantage of using geothermal energy as a source is that this energy does not require back-up system like batteries to store energy and the energy can supply base load electricity throughout the year and the $\mathrm{CO}_{2}$ emissions are lower compared to fossil fuels (Fig. 5).

The land footprint for geothermal power plants is small compared to other renewable-based power plants. Geothermal power plants need only about 1 acre of land to generate $1 \mathrm{MWe}$ while solar pv and wind need $>7$ acres of land to generate similar power $[2,10]$. The current cost of electricity generated by solar pv is $>0.35 \mathrm{US} \$ / \mathrm{kWh}$, and in the case of geothermal, it is $<0.017 \mathrm{US} \$ / \mathrm{kWh}$ (Fig. 4). In the future (2020), the cost of geothermal is expected to reduce $<0.01 \mathrm{US} \$ / \mathrm{kWh}$ [55].

\section{Discussion}

According to FAO [56], by the year 2050, world population will need $60 \%$ more food than it is producing at present [57]. This increase will require more water and land for increasing the agricultural output. The Institute for Water Management stated that water being a finite commodity, meeting future food demand needs productive use of available fresh water [58]. However, realising the fact that sea is going to be the main source of fresh water for all the future needs, desalination technology has taken a lead, especially in MENA (Middle East and North Africa) and sub-Saharan countries, with Egypt and Kuwait setting the trend followed by Saudi Arabia.

Fresh water demand in GCC countries is maximum, especially in Saudi Arabia where the annual population growth is $6 \%$ and the anticipated demand for fresh water is of the order of 1.6 billion $\mathrm{m}^{3}$ by the year $2020[2,55]$. The minimum amount of electricity required to generate this volume of desalinated water is about $3200 \times$ $10^{6} \mathrm{kWh}[48,52]$. Even though reasonable amount of electricity is co-generated during desalination process, the amount of $\mathrm{CO}_{2}$ emitted is of the order of $4 \mathrm{~kg} / \mathrm{m}^{3}$ of desalinated water generated [48]. If the cost associated with cleansing the environment is considered, then the cost of desalinated water is not economical. Although nuclear energy-sourced desalination process is cost-effective compared to other renewables, the main issues related to this option is waste disposal, safety and the volume of nuclear raw material needed to generate large volumes of desalinated water for future population [59-61].

Financial institutions and $\mathrm{UN}$ aid institutions provide temporary relief to the rural population to tide over the water crisis by providing water through tankers [6] and draw master plan for improving the food crisis in Djibouti [3]. These are not permanent solution to the water and food crisis faced by the people. The amount of financial aid over the years to Djibouti to overcome the poverty is significantly large. Recently, UNICEF [6] published that nearly 1.6 million US\$ is required to provide health, sanitation and food for the rural population and the refugees moved in from the neighbouring countries like Yemen Republic. Such aid can be utilized to develop the geothermal sites at L. Asal and L. Abhe that can provide perennial fresh water to the entire country supporting 900,000 populations. As described above, the cost of desalinated water through geothermal energy is very low and can be affordable both by the government initially and by the population subsequently as their per capita GDP rises due to agricultural boom and employment. The country's GDP will rise when food and energy imports decline. Geothermal energy-based desalination process was not in focus until 2004. After the installation of $80 \mathrm{~m}^{3}$ capacity geothermal-sourced desalination

Table 4 Energy requirement, $\mathrm{CO}_{2}$ emissions and unit cost of desalination plants using conventional and renewable energy sources

\begin{tabular}{|l|c|c|c|c|}
\hline & Oil & Solar & Wind & Geothermal \\
\hline Power input $\mathrm{kWh} / 1000 \mathrm{~L}$ & 6 & 6 & 6 & 6 \\
\hline Cost US\$/1000L & 21 & 15 & 8 & $1.6^{*}$ \\
\hline $\mathrm{CO}_{2}$ emissions kg/1000 L & 4 & 0 & 0 & $0.4^{* *}$ \\
\hline
\end{tabular}

Adapted from [2, 53]; **source: [10]; *source: [54] 
plant in Milos Island in Greece, Pacific island countries with considerable geothermal sources are keen in establishing such plants (http://www.thinkgeoenergy.com/category/technology/, accessed on 29 March 2019; [62]). The cost of fresh water generated using geothermal energy is cost-effective compared to that generated from desalination plants supported by fossil fuels (Table 4). For countries like Djibouti, this energy is best suited to generate fresh water and support the basic needs of the rural Djibouti population.

\section{Conclusions}

Water management for agriculture is a multidisciplinary study that cuts across science, technology and administration. This cross-discipline knowledge provides methods and technologies suitable to provide food security to countries like Djibouti that are living under the cloud of poverty for decades. Such countries are at the mercy of natural precipitation to support agriculture or heavily depend on virtual water trade for sustenance. With the increasing in carbon dioxide levels in the atmosphere and consequent climate change, such countries are worst affected due to vagaries of monsoon. In spite of such hardships, Djibouti can mitigate adversities of monsoon and droughts using geothermal energy resources that is available in plenty. Rural population can improve their lifestyle, live above the poverty line and improve their socio-economic status. The local governments also should play an important role in advising the funding institutions to develop geothermal power projects to support agricultural activity and create employment to the rural population.

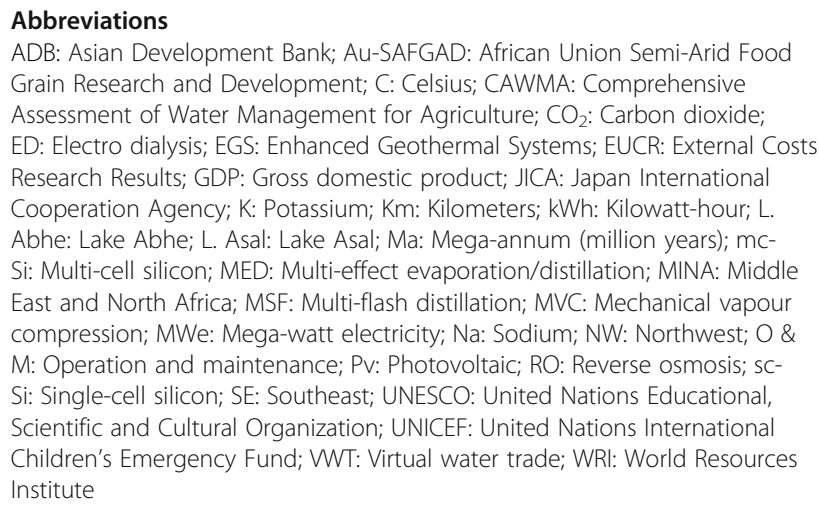

\section{Acknowledgements}

The authors extend their appreciation to the International Scientific Partnership Program (ISPP) at King Saud University for funding this work through ISPP\# 0099. DC thanks the Director, IIT Hyderabad for providing logistics in the preparation of this manuscript.

\section{Authors' contributions}

The share of responsibility for this article is equal for all the authors. All authors have read and approved the final manuscript.
Funding

There is no specific funding allotted for writing this paper.

Availability of data and materials

Not applicable

Ethics approval and consent to participate

Not applicable

Consent for publication

Not applicable

\section{Competing interests}

The authors declare that they have no competing interests.

\section{Author details}

${ }^{1}$ India Institute of Technology Hyderabad, Hyderabad 502285, India. ${ }^{2}$ King Saud University, Riyadh, Saudi Arabia. ${ }^{3}$ Department of Petroleum and Gas Engineering, King Saud University, Riyadh, Saudi Arabia. ${ }^{4}$ Department of Geology and Geophysics, College of Science, King Saudi University, Riyadh, Saudi Arabia. ${ }^{5}$ Department of Geology, King Saud University, Riyadh, Saudi Arabia. ${ }^{6}$ GeoSyndicate Power Pvt. Ltd., Mumbai, India.

Received: 25 October 2018 Accepted: 3 June 2019

Published online: 18 June 2019

\section{References}

1. WRI. WATER Mapping, measuring, and mitigating global water challenges. 2017 [cited 17 Dec 2017]

2. Chandrasekharam D et al (2018) Desalination of seawater using geothermal energy for food and water security: Arab and Sub-Sahara countries. In: Gnaneswar G (ed) Handbook on sustainable desalination handbook process design and implementation strategies. Elsevier Pub, p 54

3. JICA (2014) The master plan study for sustainable irrigation and farming in southern Djibouti, Final report submitted to the Ministry of agriculture, water, fisheries, livestock and marine resources, Republic of Djibouti, p 283

4. UNESCO, Status of food security in Africa. Eighth Session of the Committee on Food Security and Sustainable Development and Regional Implementation Meeting for the Twentieth Session of the Commission on Sustainable Development. 2012. p. 27

5. ADB, Water supply and sanitation in 1) The rural areas of Tadjoura, Arta and Ali Sabieh districts; 2) The district centres of Tadjoura and Ali Sabieh, Republic of Djibouti. 2012. p. 27

6. UNICEF (2012) Funding proposals for water and sanitation emergency response to drought in Djibouti, p 4

7. WB (2012) Project performance assessment report- Republic of Djibouti: food crisis response development policy grant, p 56

8. Jalludin M, Razack M (2004) Assessment of hydraulic properties of sedimentary and volcanic aquifer systems under arid conditions in the Republic of Djibouti (Horn of Africa). Hydrogeol J 12(2):159-170

9. AU-SAFGRAD (2015) Challenges and opportunities for strategic agricultural commodity value chains development in the IGAD region, $p 89$

10. Chandrasekharam D, Bundschuh J (2008) Low-enthalpy geothermal resources for power generation, vol 172. CRC Press Leiden

11. Mlynarski M, Zlotnicki J (2001) Fluid circulation in the active emerged Asal rift (east Africa, Djibouti) inferred from self-potential and Telluric-Telluric prospecting. Tectonophysics 339(3-4):455-472

12. Barberi F, Varet J (1970) The Erta Ale volcanic range (Danakil depression, northern afar, Ethiopia). Bull Volcanol 34(4):848-917

13. Morton WH, Black R (1975) Afar depression of Ethiopia. In: Afar Depression of Ethiopia, Proceedings of an International Symposium on the Afar Region and Related Rift Problems, Bad Bergzabern. E. Schweizerbart_sche Verlagsbuchhandlung, F.R

14. Varet J (1978) In: Gasse F (ed) Geology of central and southern Afar (Ethiopia and Djibouti Republic). CNRS, Paris, p 118

15. Makris J, Ginzburg A (1987) The Afar Depression: transition between continental rifting and sea-floor spreading. Tectonophysics 141(1-3): 199-214

16. Bosworth W, Huchon P, McClay K (2005) The Red Sea and Gulf of Aden basins. J Afr Earth Sci 43(1-3):334-378 
17. Lahitte $P$ et al (2003) New age constraints on the timing of volcanism in central Afar, in the presence of propagating rifts. J Geophys Res: Solid Earth 108(B2):2123-2143

18. Houssein B et al (2013) Geochemistry of thermal springs around Lake Abhe, Western Djibouti. Int J S Energy 33(6):1090-1102

19. Chandrasekharam D et al (2016) Red Sea geothermal provinces, vol 222, 1st edn. CRC Press

20. Barberi F et al (1975) In: Pilger A, Roesler A (eds) Structural evolution of the Afar triple junction, in Afar depression of Ethiopia. Schweizerbart, Stuttgart, pp 39-53

21. Black M, Morton WH, Rex DC (1974) Block tilting and volcanisme within the Afar in the light of recent KAr age data. In: Pilger A, Rösler A (eds) Afar Depression of Ethiopia. Stuttgart: E. Schweizerbart'sche Verlagsbuchhandlung; F.R pp 269-299

22. Deniel $C$ et al (1994) Temporal evolution of mantle sources during continental rifting: the volcanism of Djibouti (Afar). J Geophys Res: Solid Earth 99(B2):2853-2869

23. Sakindi G (2015) Three-dimensional inversion of magnetotelluric data: geological/geothermal interpretation of Asal geothermal field, Djibouti, in Faculty of Earth Sciences. University of Iceland, Iceland, p 125

24. Fouillac AM et al (1989) Water-rock interaction between basalt and highsalinity fluids in the Asal Rift, Republic of Djibouti. Chem Geol 76(3-4):271-289

25. Zan L et al (1990) Geothermal exploration in the Republic of Djibouti: thermal and geological data of the Hanlé and Asal areas. Geothermics 19(6): 561-582

26. Bosch B et al (1977) The geothermal zone of lake Assal (F.T.A.I), geochemical and experimental studies. Geothermics 5(1-4):165-175

27. Jalludin, M., State of knowledge of the geothermal provinces of the Republic of Djibouti, in Short Course IV on Exploration for Geothermal Resouces. 2009 organized by UNU-GTP, KenGen and GDC: Lake Naivasha. p. 1-22

28. Fournier RO, Potter RW (1979) Magnesium correction to the Na-K-Ca chemical geothermometer. Geochim Cosmochim Acta 43(9):1543-1550

29. Moussa, O.A. and H. Suleiman. Country report, geothermal development in Djibouti, in Proceedings, World Geothermal Congress 2015. 2015: Melbourne

30. Assad MEH, Bani-Hani E, Khalil M (2017) Performance of geothermal power plants (single, dual and binary) to compensate for LHC-CERN power consumption: comparative study, Geotherm Energy, vol 5, p 17

31. Giggenbach WF (1988) Geothermal solute equilibria. Derivation of Na-K-MgCa geoindicators. Geochim Cosmochim Acta 52(12):2749-2765

32. Chandrasekharam D et al (2018) Geochemical evolution of geothermal fluids around the western Red Sea and East African Rift geothermal provinces. J Asian Earth Sci 164:292-306

33. DiPippo R (1999) Small geothermal power plants: design, performance and economics, GHC Bulletin, pp 1-8

34. Nusiaputra YY, Wiemer H-J, Kuhn D (2014) Thermal-economic modularization of small, organic Rankine cycle power plants for midenthalpy geothermal fields. Energies 7(7):4221-4240

35. Stefánsson V (2002) Investment cost for geothermal power plants. Geothermics 31(2):263-272

36. Ngugi P (2012) What does geothermal cost? The Kenya Experience. Short coures, UN-GTP. United Nationas Geothermal Training Programme, Naivasha, p 13

37. Serdjuk M et al (2013) Geothermal investment guide. GEOELEC project report (European Union), p 40

38. Breeze, P., The cost of power generation. The current and future competitiveness of renewable and traditional technologies. "Energy" Business Insights Ltd, Management Report. 2010. p. 147

39. Fridleifsson IB, Freeston DH (1994) Geothermal energy research and development. Geothermics 23(2):175-214

40. Louwen A et al (2016) Re-assessment of net energy production and greenhouse gas emissions avoidance after 40 years of photovoltaics development. Nat Commun 7:13728

41. Alsema, E.A. Energy requirements and CO2 mitigation potential of PV system. in Workshop "PV and the Environment 1998" National Renewable Energy Laboratory. 1998. Keystone: Utrecht University Repository

42. EUCR (2003) External costs: research results on socio-environmental damages due to electricity and transport, European Commission Community Research. EUR 20198, p 28
43. Fthenakis $V$, Alsema $E$ (2006) Photovoltaics energy payback times, greenhouse gas emissions and external costs: 2004-early 2005 status. Prog Photovolt 14(3):275-280

44. Reich NH et al (2007) CO2 emissions in the perspective of PV a renewable energy economy. In: 22nd European Photovoltaic Solar energy Conference, Milan

45. Fthenakis $V$ et al (2011) Life cycle inventories and life cycle assessment of photovoltaic systems. In: Photovoltic power systems programme (PVPS), p 63

46. Fridleifsson IB (2001) Geothermal energy for the benefit of the people. Renew Sust Energ Rev 5(3):299-312

47. Fiorenza G, Sharma VK, Braccio G (2003) Techno-economic evaluation of a solar powered water desalination plant. Energy Convers Manag 44(14): 2217-2240

48. Ghaffour N et al (2014) Renewable energy-driven innovative energy-efficient desalination technologies. Appl Energy 136:1155-1165

49. Reddy KV, Ghaffour N (2007) Overview of the cost of desalinated water and costing methodologies. Desalination 205(1-3):340-353

50. Kalogirou SA (2005) Seawater desalination using renewable energy sources. Prog Energy Combust Sci 31(3):242-281

51. Gude VG (2015) Energy storage for desalination processes powered by renewable energy and waste heat sources. Appl Energy 137:877-898

52. Gude VG, Nirmalakhandan N, Deng S (2010) Renewable and sustainable approaches for desalination. Renew Sust Energ Rev 14(9):2641-2654

53. Abazza H (2012) Economic considerations for supplying water through desalination in south Mediterranean countries, sustainable water integrated management-support mechanism (SWIM-SM), Project funded by the European Union Economic, pp 1-48

54. Karytsas C, Mendrinos D, Radoglou G (2004) The current geothermal exploration and development of the geothermal field of Milos Island in Greece. GeoHeat Centre Quarterly Bulletin 25(2):17-21

55. Chandrasekharam D (2018) Water for the millions: focus Saudi Arabia. Water-Energy Nexus 1(2):142-144

56. FAO (2009) How to feed the world in 2050. In: Proceedings of the expert meeting on how to feed the world in 2050. Food and Agriculture Organization of the United Nations, Rome

57. Alexandratos N, Bruinsma J (2012) World agriculture towards 2030/2050: the 2012 revision. FAO, Rome, p 154

58. CAWMA (2007) In: Molden DJ (ed) Water for food, water for life: a comprehensive assessment of water management in agriculture. International Water Management Institute, London

59. Al-Mutaz IS (2001) Potential of nuclear desalination in the Arabian Gulf countries. Desalination 135(1-3):187-194

60. Aljohani MS (2004) Nuclear desalination competitiveness in the western region of the Kingdom of Saudi Arabia. Desalination 164(3):213-223

61. Mansouri NY, Ghoniem AF (2017) Does nuclear desalination make sense for Saudi Arabia? Desalination 406:37-43

62. McCoy West AJ et al (2011) Geothermal resources in the Pacific Island: the potential of power generation to benefit indigenous communities. In: Thirty-sixth workshop on Geothermal Reservoir Engineering Stanford University. Stanford University, Stanford

\section{Publisher's Note}

Springer Nature remains neutral with regard to jurisdictional claims in published maps and institutional affiliations.

Ready to submit your research? Choose BMC and benefit from:

- fast, convenient online submission

- thorough peer review by experienced researchers in your field

- rapid publication on acceptance

- support for research data, including large and complex data types

- gold Open Access which fosters wider collaboration and increased citations

- maximum visibility for your research: over $100 \mathrm{M}$ website views per year

At $\mathrm{BMC}$, research is always in progress.

Learn more biomedcentral.com/submission 